\title{
Farmers' Perceptions of Local Food Procurement, Mississippi, 2013
}

Nathan Rosenberg, JD; Nhan L. Truong, PhD; Tyler Russell, BS; Deja Abdul-Haqq, BA; June A. Gipson, PhD; DeMarc A. Hickson, PhD; for the Project CHANGE Leadership Team

Suggested citation for this article: Rosenberg N, Truong NL, Russell T, Abdul-Haqq D, Gipson JA, Hickson DA, et al. Farmers' Perceptions of Local Food Procurement, Mississippi, 2013. Prev Chronic Dis 2014;11:140004. DOI: http://dx.doi.org/10.5888/pcd11.140004 圈.

PEER REVIEWED

\section{Abstract}

We sought to understand the experiences and perceptions of food producers regarding food procurement programs for local institutions. A total of 72 (45\%) Mississippi fruit and vegetable growers completed a mailed survey, and of those that reported selling to local businesses and institutions (54\%), few were selling to schools (13\%). The primary motivations to sell to institutions were to increase profits (67\%) and to improve nutrition within their communities (57\%), while the most commonly reported barrier was a lack of knowledge about how to sell to institutions (39\%). Farm to institution programs must develop evidence-based practices designed to address barriers to producers' participation in local institutional food procurement programs.

\section{Objective}

Food procurement from local farmers by local institutions (F2I) is becoming increasingly widespread. In the United States, the most well-known type of F2I, farm to school (F2S), has quadrupled over the past decade $(1,2)$. F2S programs, including national model programs such as the Green Mountain Farm to School project in Vermont, promote health and improve children's access to fruits and vegetables by linking schools to locally grown foods $(3,4)$. In Mississippi, more than 15\% of school districts reported having a F2S program in 2012 compared with none in 2010 $(5,6)$. As programs for local institutional food procurement expand, it is important to understand the barriers to and motivations for food producers' participation in F2S programs. We describe a study of Mississippi growers' perceptions of, barriers to, and motivations for participation in local institutional food procurement programs.

\section{Methods}

We used a cross-sectional survey design to assess the needs of Mississippi fruit and vegetable producers, including the experiences and perceptions of food producers in local institutional food procurement programs in Mississippi. This work was supported in part by an award to My Brother's Keeper, Inc (MBK), from the Community Transformation Grant Program, a national effort of the Centers for Disease Control and Prevention to implement community-level chronic disease prevention interventions (7). The survey of Mississippi fruit and vegetable growers was developed and administered by a team of investigators from Delta Directions and MBK. The team vetted the survey sampling, survey construction, and response formats. The survey was refined by conducting pilot surveys with 11 local food producers and food procurement experts. The survey contained questions related to food production and safety and food producers' perceived barriers to and motivations for participating in local institutional food procurement programs. A copy of the survey is in theAppendix.

We obtained contact information for Mississippi fruit and vegetable growers from grower cooperatives and advocacy organizations. We also found grower contact information using 2 websites: Mississippi MarketMaker

(http://ms.marketmaker.uiuc.edu/) and Local Harvest (http://www.localharvest.org). In total, 159 fruit and vegetable growers were identified and mailed a survey during March 2013 through July 2013. In an introductory letter, growers were informed that completing the survey signified their consent to participate in the survey and to allow us to use the collected information in reports, publications, or presentations. Growers were also informed that their personal 
contact information would not be used in reports, publications, or presentations and would not be shared with anyone seeking to contact local growers. Growers were asked to return the completed survey in the provided stamped, selfaddressed envelope. The MBK Institutional Review Board approved the use of these data for this study. Descriptive statistics, including proportions for categorical variables, were generated in SPSS version 21 (IBM Corp, Armonk, New York).

\section{Results}

A total of 72 (45\%) growers returned the survey. Most participants (54\%) reported owning less than 50 acres of land, and $\mathbf{2 8 \%}$ reported having some type of food safety certification (eg, US Department of Agriculture's Good Agricultural Practices and Good Handling Practices). More than three-fourths of growers primarily sold food locally through either direct-to-consumer sales such as farmers markets (61\%) or on-farm sales (28\%), or intermediate marketing venues, such as local restaurants, institutions, or stores (49\%).

Most growers who reported selling to local businesses and institutions sold directly to noninstitutional local purchasers such as restaurants (69\%) and grocery stores (51\%); fewer sold to local schools (13\%) (Table). None of the growers reported selling directly to other institutions such as hospitals, institutions of higher education, or prisons. Of the 33 respondents who had not previously sold to local institutions, 8 (24\%) indicated that they were interested in doing so. The chief barriers identified by growers for not selling to institutions was a lack of knowledge about how to sell to schools and other institutions (39\%) and crops not being ready for harvesting during the academic school year (24\%). Other barriers included low prices paid by schools and other institutions, insurance costs, and an imbalance between supply and demand.

Overall, growers were motivated to sell to local institutions out of a desire to increase profits (67\%), improve nutrition in their community (57\%), increase awareness of agricultural practices among students and nongrowers (46\%), support their local community (44\%), and exercise good public relations (38\%). Most growers also indicated that they would be interested in either having students visit their farm as part of a school field trip (58\%) or visiting a classroom themselves to discuss agriculture or the importance of local food with school-aged children (57\%).

\section{Discussion}

Most Mississippi fruit and vegetable growers sell their food locally, although mainly at local farmers markets and to restaurants and grocery stores. Our findings were consistent with those from other studies $(8,9)$ that documented perceived barriers to selling to schools and other institutions to be the small amount paid by institutions, the quantities demanded by institutions (ie, either too small or too large), and costly insurance premiums. Our findings extend the current literature by identifying additional perceived barriers: 1) misalignment of crop harvesting with the academic school year and 2) lack of knowledge about how to sell to local schools and other institutions. Growers were interested in selling to local institutions for economic and social reasons, including increased profits and improving community nutrition, a finding similar to those of previous studies $(4,8-11)$.

Further expansion of F2I could have a substantial effect on health and nutrition in Mississippi. A review article reported that F2I programs in K through 12 schools increase the amount of fruits and vegetables consumed by students in the cafeteria, classroom, and at home; they also increase students' knowledge about healthy eating (12). Although our survey was limited to Mississippi growers, these findings suggest that future policy and programs to expand F2I must identify and address farmers' perceived barriers to participation if local food procurement initiatives are to reach their full potential. Policy recommendations include instituting a mini-grant program, providing tax incentives for growers who sell products to local institutions, establishing a statewide F2S week, ensuring that schools can impose a geographic preference when purchasing local food products, and creating a statewide F2I program charged with providing farmers with technical assistance and training $(5,13)$. F2I advocates, such as the Mississippi Food Policy Council, are seeking to address the knowledge gap among farmers through informal outreach, a statewide training conference, regional networking workshops, and selling guides for farmers. These efforts should be studied carefully, allowing evidence-based methods to be developed and replicated elsewhere.

\section{Acknowledgments}

This manuscript was supported in part by a Cooperative Agreement with the Centers for Disease Control and Prevention ( ${ }_{5} \mathrm{U}_{5} 8 \mathrm{D}$ 003711). However, the findings and conclusions in this paper are those of the authors and do not necessarily represent the official position of the Centers for Disease Control and Prevention. Users of this document should be aware that every funding source has different requirements governing the appropriate use of those funds. Under US law, no Federal funds are permitted to be used for lobbying or to influence, directly or indirectly, specific pieces of pending or proposed legislation at the federal, state, or local levels. Organizations should consult appropriate legal counsel to ensure compliance with all rules, regulations, and restriction of any funding sources. 
We thank the Mississippi fruit and vegetable growers for their time and commitment to expanding F2I programs in the state. We also thank the other members of the investigative team: Honoray Ard, Carroll Frazier, Shamir Lee, Christopher Roby, and Dantrell Simmons.

\section{Author Information}

Corresponding Author: DeMarc A. Hickson, PhD, Center for Research, Evaluation, and Environmental and Policy Change, 5420 I-55 North, Suite A, Jackson, MS 39211. Telephone: 601-898-0000, extension 115. E-mail:

dhickson@mbk-inc.org.

Author Affiliations: Nathan Rosenberg, Tyler Russell, Delta Directions, Clarksdale, Mississippi; Nhan L. Truong, Deja Abdul-Haqq, Center for Research, Evaluation and Environmental and Policy Change, My Brother's Keeper, Inc, Jackson, Mississippi; June A. Gipson, Center for Community-Based Programs, My Brother's Keeper, Inc, Ridgeland, Mississippi.

\section{References}

1. Feenstra G, Ohmart J. The evolution of the School Food and Farm to School Movement in the United States: connecting childhood health, farms, and communities. Child Obes 2012;8(4):280-9. PubMed 国

2. Farm to School: nourishing kids and community. Chicago (IL): National Farm to School Network; 2011. http://www.farmtoschool.org/. Accessed October 5, 2013.

3. Harris D, Lott M, Lakins V, Bowden B, Kimmons J. Farm to institution: creating access to healthy local and regional foods. Adv Nutr 2012;3(3):343-9. CrossRef 国 PubMed 国

4. Pinard CA, Smith TM, Carpenter LR, Chapman M, Balluff M, Yaroch AL. Stakeholders' interest in and challenges to implementing farm-to-school programs, Douglas County, Nebraska, 2010-2011. Prev Chronic Dis 2013;10:E210. CrossRef 国 PubMed 国

5. Rosenberg N, Broad Leib E. Expanding farm to school in Mississippi: analysis and recommendations. Boston (MA): Harvard Law and Food Policy Clinic.

http://blogs.law.harvard.edu/foodpolicyinitiative/files/2011/o9/Expanding-Farm-to-School-in-Mississippi.pdf. Accessed October 7, 2013.

6. Lingsch KJ. Mississippi's First Annual Farm to School Week: evaluation of school participation [master's thesis]. Hattiesburg (MS): University of Southern Mississippi; 2013.

7. Community Transformation Grant (CTG) Program fact sheet. Atlanta (GA): Centers for Disease Control and Prevention, National Center for Chronic Disease Prevention and Health Promotion, Division of Community Health; 2013. http://www.cdc.gov/nccdphp/dch/programs/communitytransformation/funds/index.htm. Updated October 25, 2013. Accessed January 3, 2014.

8. Vogt RA, Kaiser LL. Still a time to act: a review of institutional marketing of regionally-grown food. Agric Human Values 2008;25(2):241-55. CrossRef 圈

9. Setala A, Gittelsohn J, Speakman K, Oski J, Martin T, Moore R, et al. Linking farmers to community stores to increase consumption of local produce: a case study of the Navajo Nation. Public Health Nutr 2011;14(9):165862. CrossRef圈 PubMed 圈

10. Conner D, King B, Kolodinsky J, Roche E, Koliba C, Trubek A. You can know your school and feed it too: Vermont farmers' motivations and distribution practices in direct sales to school food services. Agric Human Values 2012;29(3):321-32. CrossRef 圈

11. Izumi BT, Wright DW, Hamm MW. Market diversification and social benefits: motivations of farmers participating in farm to school programs. J Rural Stud 2010;26(4):374-82. CrossRef

12. Joshi A, Azuma AM, Feenstra G. Do farm-to-school programs make a difference? Findings and future research needs. J Hunger Environ Nutr 2008;3(2-3):229-46. CrossRef 圈

13. Harvard Law School Health Law and Policy Clinic and Harvard Law School Mississippi Delta Project. Legislative recommendations for a statewide farm-to-school bill in Mississippi. Boston (MA): Harvard Food Law and Policy Clinic; 2011. http://blogs.law.harvard.edu/foodpolicyinitiative/files/2011/o9/FTS-legis-recs-FINAL-12-5.pdf. Accessed October 7, 2013.

\section{Table}


Preventing Chronic Disease | Farmers' Perceptions of Local Food Procurement, Mississip... Page 4 of 4

Table. Proportion of Mississippi Fruit and Vegetable Growers $(\mathrm{n}=$ 72) Selling to Local Institutions and Businesses and the Perceived Barriers Among Growers Who Do Not Currently Sell to Local Institutions or Businesses, 2013

\begin{tabular}{|c|c|}
\hline Participation or barrier & n (\%) \\
\hline Participate in local food procurement programs & $39(54)$ \\
\hline Schools & $5(13)$ \\
\hline Other institutions such as universities and hospitals & 0 \\
\hline Local restaurants & $27(69)$ \\
\hline Local grocery stores & $20(51)$ \\
\hline Convenience stores & $2(5)$ \\
\hline Barriers to participation & $33(46)$ \\
\hline Not sure how to do it & $13(39)$ \\
\hline Price paid is not high enough & $4(12)$ \\
\hline Can make more money selling elsewhere & $1(3)$ \\
\hline My crops aren't ready during the school year & $8(24)$ \\
\hline Schools want graded size; I can't provide & $2(6)$ \\
\hline Quantities wanted are too small & $2(6)$ \\
\hline Quantities wanted are too large & $3(9)$ \\
\hline Costly insurance & $2(6)$ \\
\hline
\end{tabular}

Appendix. Mississippi Fruit and Vegetable Growers Survey

This file is available for download $\overline{\bar{Z}}$ as an Adobe Acrobat Reader document. [PDF - $554 \mathrm{~KB}$ ].

The opinions expressed by authors contributing to this journal do not necessarily reflect the opinions of the U.S.

Department of Health and Human Services, the Public Health Service, the Centers for Disease Control and Prevention, or the authors' affiliated institutions.

For Questions About This Article Contact pcdeditor@cdc.gov

Page last reviewed: June 26, 2014

Page last updated: June 26, 2014

Content source: National Center for Chronic Disease Prevention and Health Promotion

Centers for Disease Control and Prevention 1600 Clifton Rd. Atlanta, GA 30333, USA

80o-CDC-INFO (800-232-4636) TTY: (888) 232-6348 - Contact CDC-INFO

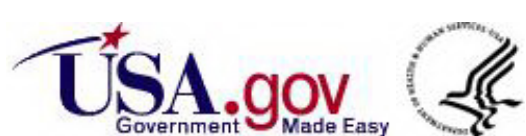

